\section{"The first shot": the context of first injection of illicit drugs, ongoing injecting practices, and hepatitis C infection in Rio de Janeiro, Brazil}

\author{
O contexto da primeira injeção de drogas ilícitas, \\ práticas atuais de injeção e infecção pelo vírus \\ da hepatite $C$ no Rio de Janeiro, Brasil
}

\begin{abstract}
The context of first drug injection and its association with ongoing injecting practices and $\mathrm{HCV}$ (hepatitis $C$ virus) infection were investigated. Injection drug users (IDUs) $(N=606)$ were recruited in "drug scenes" (public places, bars) in Rio de Janeiro, Brazil, interviewed, and tested for HCV. Sharing of needles/syringes was more prevalent at the first injection (51.3\%) than at the baseline interview (36.8\%). Those who shared syringes/needles at first injection were more likely to be currently engaged in direct/indirect sharing practices. Among young injectors (<30 years), those reporting sharing of needles/ syringes at the first injection were about four times more likely to have been infected by HCV. Hepatitis $C$ virus prevalence among active IDUs ( $n=272)$ was $11 \%$. Prison history and longer duration of drug injection were identified as independent predictors of HCV infection. To effectively curb HCV transmission among IDUs and minimize harms associated with risk behaviors, preventive strategies should target individuals initiating drug injection beginning with their very first injection and discourage the transition from non-injecting use to the self-injection of illicit drugs.
\end{abstract}

Intravenous Substance Abuse; Needle Sharing; Hepatitis C Virus; Street Drugs
Maria de Lourdes Aguiar Oliveira 1

Mariana A. Hacker ${ }^{2}$

Sabrina Alberti Nóbrega de Oliveira ${ }^{1}$

Paulo Roberto Telles 3

Kycia Maria Rodrigues do Ó 1

Clara Fumiko Tachibana Yoshida 1

Francisco I. Bastos 2

\section{Introduction}

Globally, drug abuse is of major concern, affecting about $3 \%$ of the world population. As of late 2003, the population of injection drug users (IDUs) was estimated at 13.2 million (about $0.3 \%$ of adult inhabitants) worldwide 1 .

Injection drug users play a key role in hepatitis $\mathrm{C}$ virus (HCV) infection epidemiology and are associated with up to $90 \%$ of reported hepatitis C cases in many countries 2,3. Drug injectors are frequently engaged in risky behaviors such as sharing needles/syringes and other injection paraphernalia 4,5,6, favoring rapid and extensive HCV spread throughout IDUs networks. Accordingly, high HCV infection prevalence rates $(65-98 \%)$ have been reported in different contexts $7,8,9,10$. Recently, a declining prevalence of blood-borne pathogens has been described among IDUs in some contexts, such as the United States, Spain, and Brazil 11,12,13,14. Despite such auspicious findings, the prevalence of HCV infection remains unacceptably high.

Hepatitis $C$ virus infection appears to occur early in the drug injection "career". Previous reports show that HCV seroconversion takes place within a period of a few months to about 3 years since the first drug injection 6,15. Hence, early preventive interventions should target beginners, as young and/or new (short-term) injectors. Some authors suggest that circum- 
stances, behaviors, and practices observed at the first injection are critical and may be reproduced along their "drug injection careers". However, literature on this matter has been scarce worldwide 10,16,17,18,19 and absent in Brazil.

In the present study, the context and behaviors at the first injection and its putative relationship with subsequent injecting practices were explored, as well as the association between such behaviors and HCV infection among young injectors. The prevalence and predictors of HCV infection among active IDUs were also discussed.

This information is pivotal to implement preventive strategies directed to young drug users who have not started to inject and/or to prevent harmful practices among those commencing to inject. In the absence of an immunopreventive alternative (to date, no vaccine has been developed against hepatitis $\mathrm{C}$ ), health interventions against HCV infection rely basically on the prompt identification of vulnerable populations and the effort to change their behaviors toward safer ones.

This study is part of the WHO Drug Injection Study Phase II, a multi-city study of injecting drug use carried out in cities from Argentina, Brazil (3 sites), Belarus, China, Colombia, Iran, Kenya, Malaysia, Nigeria, Russian Federation, Ukraine, Vietnam, Bangkok, and the United States (New York). The study was designed to provide policy- and decision-makers with comprehensive and reliable information for intervention development on injecting drug use and its health consequences by conducting rapid assessments linked with behavioral and seroprevalence (HIV, hepatitis B and C) surveys among injection drug users.

\section{Subjects and methods}

\section{Population}

From October 1999 to December 2001, 606 IDUs were recruited from "drug scenes" (public places, nightclubs, and bars) in different areas of Rio de Janeiro, Brazil. The targeted communities were defined after a comprehensive effort of interviewing key informants and drug users from different communities using indepth interviews and focus groups, according to World Health Organization (WHO) guidelines, after Watters \& Biernacki's 20 original contribution on targeted sampling procedures.

The field work was coordinated by the Syringe-exchange Program (SEP) at the Center for Research on Care for Drug Use at the Uni- versidade do Estado do Rio de Janeiro (NEPAD/ UERJ), drawing on the expertise and experience of a team of outreach workers. A mobile unit (van) was used to recruit volunteers and transport them back and forth from the SEP assessment center.

A concentrated effort was made to recruit individuals representing the diversity of Rio de Janeiro's social geography. No drug users were recruited from drug treatment centers, but the sample included a small proportion (17\%) of interviewees engaged in drug treatment programs for less than one month, as defined by the study inclusion criteria. Among the drug users with a history of drug injection, 272 (44.9\%) reported having injected at least once in the previous 6 months - defined, for the purpose of the present study, as "active IDUs" -, while 334 (55.1\%) reported no injection of illicit drugs in the previous 6 months, defined here as "former IDUs".

\section{Ethical aspects and survey and laboratory procedures}

The study was approved by the Institutional Review Board of the Fundação Oswaldo Cruz. After reading and signing the informed consent form, IDUs were interviewed by a physician or psychologist from the SEP staff, using a structured questionnaire developed and piloted by the WHO collaborative group. The different sections of the questionnaire address socio-demographic information, drug use and sexual habits, drug injection-related risks and harms, and socio-medical history (including assessment of violence and overdoses). Socio-demographic, behavioral, and laboratory data were entered into an electronic form, written in Epi Info 6.2 (Centers for Disease Control and Prevention, Atlanta, USA), developed by the Brazilian team according to WHO master codes and electronic framework. Univariate, bivariate, and multivariate automatic and manual checks were performed to maximize data accuracy and consistency.

After the interview, blood samples were drawn and tested for viral hepatitis (B and C) and HIV at the National Reference Laboratory for Viral Hepatitis and at the AIDS and Molecular Immunology Laboratory, Fundação Oswaldo Cruz, respectively. All interviewees received pre- and post-test counseling. Hepatitis $C$ virusRNA positive IDUs were referred to the network of public reference hospitals for hepatitis $\mathrm{C}$ in Rio de Janeiro for further clinical evaluation and follow-up. HBV vaccination was available at no cost for those who agreed to be vaccinated. 
Hepatitis C infection was defined as the presence of HCV antibodies, detected by a commercial immunoassay (UBI HCV EIA 4.0, Beijing United Biomedical Co., Beijing, China). Initially reactive samples were retested in duplicate. Final results were given based on the concordance between at least two of the three replicates. HCV-positive samples were further submitted to HCV-RNA detection by nested polymerase chain reaction, and HCV genotyping was performed by restriction fragment length polymorphism analysis, as described elsewhere 21 . All samples were also tested for HBV serological markers and HIV infection 13,22. However, the latter information was not included in the present article.

\section{Definitions}

For the sake of the present study, "sharing of needles/syringes", was defined as someone using syringes and/or needles together with or after someone else has used them. "Duration of the injection career" was defined as the age of the interviewee at the interview date (or, in the case of former IDUs, the age of last drug injection) minus his/her age at the first injection. "First injector" was defined as the subject who executed the first drug injection, either the interviewee himself/herself or someone who injected him/her. "Exchanging of second-hand injection paraphernalia” was defined as giving, lending, renting, or selling used needles and syringes or related materials to someone else. "Front and/or backloading" were defined as splitting drugs prepared in one recipient with subsequent transfer of prepared drug from one syringe to a second syringe, via the front of the recipient syringe ("frontloading") or the back of the recipient syringe, after removing the plunger ("backloading"). IDUs aged less than 30 years were considered "young injectors".

\section{Data analysis}

Descriptive analyses of socio-demographic data, behavioral variables at the first and most recent drug injections (last 6 months) were carried out. Contingency table statistics (chi-square and Fisher's exact test and t-test for means) were employed to assess putative associations between variables related to the first injection and: (a) ongoing injection behaviors among active IDUs ( $\mathrm{n}=272$ ); and (b) HCV infection among young injectors $(n=292)$. The McNemar test was used to explore changes in sharing of needles/syringes between the first and most recent drug injections. In this analysis, only IDUs who injected for more than one year were included, in order to avoid "contamination" of information relative to the first and most recent injections.

Bivariate associations between HCV infection and socio-demographic and behavioral variables were also investigated among active IDUs. Multiple logistic regressions were carried out, considering all variables of epidemiological relevance and plausibility which were significant at the level of $\mathrm{p}<0.05$ in bivariate analyses. Colinearity and interaction between selected covariates (e.g. age, age at first injection, duration of injection drug use) was explored with the inclusion of interaction terms in multivariate models.

\section{Results}

\section{Socio-demographic data}

The socio-demographic profile of the 606 IDUs (comprising both active and former IDUs) enrolled in the study is shown in Table 1. Injection drug users investigated here belong to lower socio-cultural and economical strata. Most are single and about two-thirds are dependent on others for a place to live. Despite this unfavorable profile, only $2.6 \%$ of subjects reported illegal activities - such as drug dealing and prostitution - as a source of income. In contrast, probably due to the illegality of drug use itself, half of the interviewees reported to have been in prison at least once in their lifetime. Among those who injected while imprisoned $(n=66)$, $70.3 \%$ shared syringes and/or needles.

\section{Context and behaviors at the first injection of illicit drugs}

Table 2 summarizes the context, behaviors, and practices at the first drug injection. Interviewees started to use illicit drugs in early youth (16.6 \pm 4.1 years). In the 30 days prior to the transition to injecting drug use (which was reported to have occurred a few years later), most novice injectors reported weekly use of the same drug by a non-injecting route of selfadministration.

Cocaine was the drug of choice for debuting IDUs (89.9\%), followed by amphetamines (6.4\%). Injection of cocaine with miscellanea of other injection drugs (i.e. speedball, or cocaine + heroin, or the combined use of cocaine with amphetamines or tranquilizers), or single use of other drugs (heroin, tranquilizers, and others) were rarely mentioned. 
Socio-demographic characteristics of 606 injection drug users (IDUs).

WHO Multicity Study Phase II, Rio de Janeiro, Brazil, 1999-2001.

\begin{tabular}{|c|c|c|}
\hline Socio-demographic variables* & $\mathrm{n}$ & $\%$ \\
\hline Gender (male, \%) & 554 & 91.4 \\
\hline \multicolumn{3}{|l|}{ Schooling (\%) } \\
\hline Illiterate (never attended school) & 18 & 3.0 \\
\hline Up to 8 years & 259 & 42.7 \\
\hline More than 8 years & 329 & 54.3 \\
\hline \multicolumn{3}{|l|}{ Source of income $(\%)^{\star \star}$} \\
\hline $\begin{array}{l}\text { Informal, benefits, student financial aid, } \\
\text { income from others }\end{array}$ & 497 & 82.0 \\
\hline Permanent job & 65 & 10.7 \\
\hline Illegal activities & 16 & 2.6 \\
\hline No information & 28 & 4.7 \\
\hline \multicolumn{3}{|l|}{ Monthly income $(\%)^{\star \star}$} \\
\hline$<1$ Brazilian minimum wage ${ }^{\star \star \star}$ & 381 & 62.9 \\
\hline 2-5 times Brazilian minimum wage & 222 & 36.6 \\
\hline \multicolumn{3}{|l|}{ Marital status $(\%)^{\star \star}$} \\
\hline Single & 390 & 64.4 \\
\hline Legally married/living as married & 156 & 25.7 \\
\hline Widowed/legally separated/divorced & 60 & 9.9 \\
\hline \multicolumn{3}{|l|}{ Residence ${ }^{\star \star}$} \\
\hline Home of parents, relatives, friends; shelters & 413 & 68.2 \\
\hline Owned or rented house or apartment & 193 & 31.8 \\
\hline Ever been in prison & 269 & 44.4 \\
\hline Injected while in prison & 66 & 24.5 \\
\hline Shared injection equipment while imprisoned\# & 45 & 70.3 \\
\hline Continuous variables & \multicolumn{2}{|c|}{ mean $( \pm S D)$} \\
\hline Age (years) & \multicolumn{2}{|c|}{$32.2(9.8)$} \\
\hline
\end{tabular}

* Due to missing information, some totals do not reach $100 \%$;

$\star \star$ In the previous 6 months;

$\star \star \star$ Roughly equivalent to US\$90.00;

\# Among the 66 interviewees who reported having shared while imprisoned.

More than half $(60 \%)$ of beginners purchased the drug themselves or gave money to someone else to buy for them. Half of the interviewees $(50.7 \%)$ mentioned that the first injection took place in public places, such as schools, universities, club, bars, shelters, streets, and parks and that they had been injected first by a male friend, sex partner, or relative. These figures could possibly explain the high frequency of sharing of needles/syringes (51.3\%) reported at the first drug injection.

About a third of subjects $(31.8 \%)$ reported having initiated a mean of $2.7( \pm 3.3)$ other subjects into injecting drugs.

\section{Ongoing injection practices and sharing behaviors among active IDUs}

Information related to ongoing injection practices and equipment-sharing behaviors among the 272 active IDUs is shown in Table 3. Most IDUs were males (93.8\%), aged $30.1 \pm 9.5$ years. Mean duration of the injecting career was 9.2 $( \pm 8.9)$ years. A total of 270 individuals answered the question on main modality of drug intake. Non-injecting drug use was reported as the main route by 210 subjects $(77.8 \%)$, whereas injection was mentioned as the principal route of drug self-administration by 36 subjects (13.3\%). The remaining group (8.9\%) reported using both routes, with no clear preference. Cocaine was injected by virtually all IDUs (97.4\%). Other drugs were only injected occasionally: methamphetamines $(5.1 \%)$, heroin (2.9\%), crushed crack $(2.2 \%)$, LSD $(1.8 \%)$, and speedball (1.1\%). Finally, $82.7 \%$ of subjects reported use of marijuana or hashish in the previous 6 months.

Direct and indirect sharing of injection paraphernalia was highly prevalent. Among the 257 subjects who had injected for at least one year, $118(45.9 \%)$ reported having shared injection paraphernalia at the first injection, whereas $92(35.8 \%)$ reported currently sharing needles/syringes. "Difficulty in obtaining needles" was the most frequently mentioned $(78.2 \%)$ reason for sharing injection equipment at the baseline interview. A few interviewees (10.9\%) reported sharing injection paraphernalia based on "careful choice of sharing partners". Different modalities of syringe-mediated (indirect) drug sharing, as described by Grund et al. 23, were also reported by the interviewees. Drawing up the dissolved drug from a solution shared by others (61\%) and sharing of injecting paraphernalia like cotton and filters $(47.8 \%)$ were recurrently reported modalities of indirect sharing.

\section{Association of sharing of needles/ syringes at the first injection and ongoing sharing practices}

Injection drug users who had shared their injection equipment at the first injection were more likely to reproduce this practice over the course of their injection career than those who had injected with new syringes $(58.5 \%$ versus $16.5 \% ; p=0.003$ ). Likewise, current frequencies of indirect drug sharing were significantly higher among those who had shared needles/syringes at the first injection, compared to their counterparts (Table 4 ). 
Prevalence and predictors of HCV infection

Overall, prevalence of HCV infection was $16.8 \%$, and there was a significant association between HCV and "younger age at first drug injection" ( $p=0.038)$. A relatively low prevalence of HCV infection was found (4\%) in young injectors, but those who reported having shared needles/syringes at the first injection were four times more likely to be HCV-positive $(\mathrm{OR}=3.9)$ as compared to who had begun injecting with new (sterile) needles/syringes (Table 4).

HCV infection was found in $11 \%$ (30) of active IDUs and was significantly associated with "prison history" (ever; OR = 4.0; 95\%CI: 1.7-9.4; $\mathrm{p}=0.001$ ); "daily frequency of injecting drug use" (OR = 8.8; 95\%CI: 2.1-37.6; $\mathrm{p}=0.007)$; "older age" ( $p<0.001)$, and "longer duration of IDU career" ( $p<0.001)$ in bivariate analyses.

After multiple logistic regression (final model $\chi^{2}=44.2$; $\mathrm{p}<0.001$ ), "prison history" (adjusted OR $=3.0$; 95\%CI: 1.2-7.5) and "longer duration of injecting drug use" (adjusted OR $=1.1$; 95\%CI: 1.0-1.2) remained as independent predictors of HCV infection among active IDUs.

\section{Discussion}

This study was the first to assess the circumstances, behaviors, and practices surrounding the first drug injection and their possible association with ongoing injecting practices in the Brazilian context. This is pivotal information to prevent or delay transitions from non-injecting to injecting drug use and to implement effective harm reduction policies and interventions.

The study presents some limitations. First, despite efforts to make the sample broadly representative of the diversity in Rio de Janeiro's drug scenes, the findings cannot be extrapolated to other IDUs populations. Second, HCV prevalence was lower than expected (based on estimates from previous studies), and the small number of HCV-infected young injectors precluded multivariate analyses. Finally, the survey was not designed primarily to investigate the context and behaviors at the first drug injection.

As one of the main illicit drugs consumed in various Brazilian contexts $24,25,26$, cocaine was the drug of choice for the first injection among our interviewees and remains the most frequently injected drug, corroborating previous Brazilian findings from Rio de Janeiro 9, Santos (São Paulo) 27, and Porto Alegre (Rio Grande do Sul) 28,29.
Table 2

Behaviors and practices at first injection of illicit drugs in a sample of 606 injection drug users (IDUs). WHO Multicity Study Phase II, Rio de Janeiro, Brazil, 1999-2001.

\begin{tabular}{|c|c|c|}
\hline Context, practices and behaviors & $\mathbf{n}$ & $\%$ \\
\hline Prior non-injecting use of first drug injected ${ }^{\star}$ & 554 & 91.4 \\
\hline$>3$ times/week & 355 & 64.0 \\
\hline 1-3 times/week & 166 & 30.0 \\
\hline 1-3 times/month & 28 & 5.1 \\
\hline No previous use & 5 & 0.9 \\
\hline \multicolumn{3}{|l|}{ First drug injected } \\
\hline Only cocaine & 544 & 89.9 \\
\hline Cocaine with heroin/amphetamines/tranquilizers & 3 & 0.5 \\
\hline Amphetamines & 39 & 6.4 \\
\hline Other substances & 20 & 3.3 \\
\hline \multicolumn{3}{|l|}{ How interviewee obtained the drug } \\
\hline Bought him/herself or others on his/her behalf & 364 & 60.1 \\
\hline Received as gift & 236 & 38.9 \\
\hline Other & 6 & 1.0 \\
\hline \multicolumn{3}{|l|}{ Place of first injection } \\
\hline Public places & 307 & 50.7 \\
\hline Home of friends, sex partner, relatives & 208 & 34.3 \\
\hline Own place & 91 & 15.0 \\
\hline \multicolumn{3}{|l|}{ First injector } \\
\hline Relative, sex partner, or friend & 346 & 57.1 \\
\hline Him/herself & 129 & 21.3 \\
\hline Other & 131 & 21.6 \\
\hline \multicolumn{3}{|l|}{ First injector's gender ${ }^{\star \star}$} \\
\hline Male & 432 & 90.4 \\
\hline Female & 46 & 9.6 \\
\hline Sharing of needles and syringes at first injection ${ }^{\star \star \star}$ & 299 & 51.3 \\
\hline Continuous variables & \multicolumn{2}{|c|}{ mean $( \pm S D)$} \\
\hline Age at first drug use (years) & \multicolumn{2}{|c|}{$16.6(4.1)$} \\
\hline Age at first injection (years) & \multicolumn{2}{|c|}{$19.5(5.4)$} \\
\hline
\end{tabular}

* Thirty days before the first injection;

$\star \star N=478$;

$\star \star \star N=583$

Dunn \& Laranjeira 30 reported that $74 \%$ of cocaine users underwent at least one transition in the routes of drug administration, half of which in the first three years after initiation into cocaine abuse. Roughly one-fifth of cocaine snorters shifted to injecting cocaine (with a median interval of 12 months), whereas only $6 \%$ of injectors reverted to snorting.

Worldwide, drug injection begins at a relatively young age 10,30,31, but most subjects report a time lag between previous non-injecting use of illicit drugs and current injection 16,30. 
Table 3

Injection practices, sharing behaviors, and hepatitis $\mathrm{C}$ virus (HCV) infection among injection drug users (IDUs). WHO Multicity Study Phase II, Rio de Janeiro, Brazil, 1999-2001.

\begin{tabular}{|c|c|c|}
\hline $\begin{array}{l}\text { Injection practices, and sharing behaviors, } \\
\text { and HCV infection* }\end{array}$ & $\mathbf{n}$ & $\%$ \\
\hline Main drug used (cocaine) $)^{\star \star}$ & 265 & 97.4 \\
\hline Sharing of syringes/needles** & 100 & 36.8 \\
\hline Exchanging of used syringes/needles ${ }^{\star \star}$ & 104 & 38.4 \\
\hline \multicolumn{3}{|l|}{ Syringe-mediated drug sharing** } \\
\hline $\begin{array}{l}\text { Drawing up dissolved drug from a common } \\
\text { solution (shared by others) }\end{array}$ & 166 & 61.0 \\
\hline Sharing of injection paraphernalia (cotton, filters) & 130 & 47.8 \\
\hline Injection with a pre-filled syringe & 86 & 31.7 \\
\hline Front/ backloading & 44 & 16.2 \\
\hline \multicolumn{3}{|l|}{ HCV infection ${ }^{\star \star *}$} \\
\hline Active IDUs** & 30 & 11.0 \\
\hline Young IDUs\# & 12 & 4.0 \\
\hline Continuous variables & \multicolumn{2}{|c|}{ mean ( \pm SD) } \\
\hline Duration of IDU career (years) ${ }^{\star \star}$ & \multicolumn{2}{|c|}{$9.2(8.9)$} \\
\hline
\end{tabular}

Therefore, preventive strategies focused on this period could avert the transition from non-injecting to injecting routes 32 and reduce the incidence of blood-borne infections 33,34 .

For most IDUs, the first injector was a friend or male sex partner, with the latter a key element in the initiation of female injectors 16,18 , 19,35. The role of IDUs sex partners in HIV and HCV transmission (through needle-sharing and/or unprotected sex) $36,37,38$ and their influence on the transition from non-injecting to injecting drug use have been highlighted by the international literature. Irwin et al. 39 found that crack cocaine smokers who shifted to injecting were significantly more likely to have had an IDU partner. Similar findings were reported by Bravo et al. 40 among heroin addicts.

The finding that frequency of equipment sharing was higher at the first injection compared to current sharing habits corroborates international findings, that novice IDUs are frequently engaged in risky injecting behaviors 18,31,41, many times under a chaotic and harmful drug-consuming pattern.

This study also emphasizes the critical role of sharing needles/syringes at the first drug in- jection in ongoing risky injection practices, as previously described by the international literature 18,31 . Injection drug users who shared needles/syringes at the first injection were more likely to be currently engaged in both direct and indirect sharing, increasing the likelihood of blood-borne infections. This increased risk may explain why young injectors who began injecting with used syringe/needles were four times more likely to be HCV-positive (compared to those who used clean syringes). These findings reinforce the need to tailor prevention strategies to the specific needs of young/naïve drug users since their very first injection.

A decreasing prevalence of HCV infection has been observed among drug injectors in different contexts such as Spain 11 and the United States 12. Declining HIV infection rates 22 and hepatitis B prevalence 13 were reported by companion papers documenting the findings of the present study and comparing it with previous studies in the same population. A substantially lower HCV prevalence (11\% versus $69.6 \%$ ) was found in the present study vis-à-vis a previous assessment of the same population in Rio de Janeiro in 1994-1997 9. However, active IDUs assessed by the present study reported high frequencies of direct and indirect sharing practices, a favorable scenario for the transmission of different blood-borne pathogens 6,22,42,43 and a clear warning that there is no room for lenience.

Reduction of overall injection frequencies observed in this study (compared to previous assessments) and the initiatives aimed at reducing drug-related harm implemented in Rio de Janeiro may be contributing to the observed decline. However, other factors may contribute to the observed decline, including saturation and changes in the drug-using scene, making interpretation of the current findings rather tentative 14

Among active IDUs, HCV infection was independently associated with prison history. Imprisonment is relatively common among drug users, due to the illegal nature of their drug-consuming habits and their involvement in other illegal activities (in part, to finance the habit), probably underreported in the present study due to the associated stigma. Besides additional parenteral risks such as tattooing 44 , access to clean syringes/needles (if available) is limited in jails and prisons, favoring sharing of injecting equipment and transmission of blood-borne pathogens 45 . Longer duration of injecting drug use was also identified as an independent predictor of HCV infection, due to the cumulative exposure to HCV and other 
Bivariate associations between sharing of needles/syringes at first drug injection and current sharing practices and hepatitis C virus (HCV) infection among injection drug users (IDUs). WHO Multicity Study Phase II, Rio de Janeiro, Brazil, 1999-2001.

\begin{tabular}{|c|c|c|c|c|c|}
\hline \multirow[t]{2}{*}{ Current sharing practices* } & \multicolumn{2}{|c|}{$\begin{array}{l}\text { Sharing of needles/syringes } \\
\text { at first injection (\%) }\end{array}$} & \multirow[t]{2}{*}{ OR } & \multirow[t]{2}{*}{$95 \% \mathrm{Cl}$} & \multirow[t]{2}{*}{ p-value } \\
\hline & Yes & No & & & \\
\hline $\begin{array}{l}\text { Drawing up dissolved drug from } \\
\text { a common container (shared by others) }\end{array}$ & 75.0 & 48.6 & 3.2 & $1.9-5.4$ & $<0.001$ \\
\hline $\begin{array}{l}\text { Sharing of injection paraphernalia } \\
\text { other than needles \& syringes }{ }^{\star \star}\end{array}$ & 59.2 & 36.6 & 2.5 & $1.5-4.1$ & $<0.001$ \\
\hline Injection with a pre-filled syringe ${ }^{\star \star}$ & 46.2 & 19.0 & 3.6 & $2.1-6.3$ & $<0.001$ \\
\hline Front/backloading** & 22.5 & 9.2 & 2.8 & $1.4-5.9$ & 0.002 \\
\hline 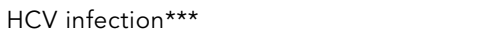 & 7.1 & 1.9 & 3.9 & $1.1-14.8$ & 0.031 \\
\hline
\end{tabular}

* In the previous 6 months;

** Among active IDUs $(\mathrm{n}=272)$;

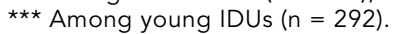

blood-borne pathogens, as previously found in Rio de Janeiro 9, Australia 7, and the United States 4,15,38,45.

Altogether, our results highlight that ongoing prevention initiatives must be reinforced and expanded as part of a comprehensive set of strategies to reduce drug-related harm, comprising continuous health education, expansion of needle exchange programs, and specific initiatives to prevent transition/relapsing into harmful injection practices. In order to effectively curb HCV transmission in this population, preventive polices should be tailored to the specific needs of novice drug injectors beginning at their very first injection and to discourage the transition from non-injecting to self-injection of illicit drugs.

\section{Resumo}

O trabalho investiga o contexto da primeira injeção de drogas e sua associação com práticas atuais de injeção e infecção pelo HCV (vírus da hepatite C). Usuários de drogas injetáveis (UDI) $(N=606)$ foram recrutados em cenas de uso (ruas, bares) do Rio de Janeiro, Brasil, entrevistados e testados (anti-HCV). A freqüência de compartilhamento de agulhas e seringas foi superior na primeira injeção (51,3\%), se comparada à atualmente referida (36,8\%). Usuários que iniciaram o uso injetável compartilhando agulhas/seringas relataram uma freqüencia significativamente maior de compartilhamento direto/indireto de agulhas/seringas nos últimos seis meses. A infecção pelo HCV foi quatro vezes mais prevalente entre UDI jovens (<30 anos) que compartilharam agulhas e seringas na primeira injeção. $A$ prevalência de anti-HCV foi $11 \%$ entre UDI ativos ( $n=$ 272) e se mostrou independentemente associada à história de prisão e à duração do uso de drogas injetáveis. A prevenção da disseminação do HCV nesta população requer a adoção de medidas de redução de riscos e danos associados à injeção de drogas já desde a primeira injeção ou, antes, um desestímulo à transição do uso não injetável para injetável.

Uso Indevido de Drogas Parenterais; Uso Comum de Agulhas e Seringas; Vírus da Hepatite C; Drogas Ilícitas 
Contributors

M. L. A. Oliveira participated in the elaboration, literature review, and drafting of the manuscript. F. I. Bastos contributed to the analysis, discussion, literature review, and drafting of the manuscript. M. A. Hacker collaborated in the analysis, discussion, and revision of the manuscript. S. A. N. Oliveira participated in the organization of the bibliography and revision of the manuscript. C. F. T. Yoshida, P. R. Telles, and K. M. R. Ó reviewed the manuscript.

\section{Acknowledgment}

This paper is based on the data and experience obtained during the WHO Drug Injection Study Phase II, a project coordinated and sponsored by the World Health Organization (WHO) and implemented by the WHO Phase II Drug Injection Collaborative Study Group. A full list of all collaborative investigators is presented in the main reports of the study.

The authors alone are responsible for the views expressed in this paper, which do not necessarily represent those of the other investigators participating in the WHO Drug Injection Study Phase II nor the views or policies of the WHO.

The Brazilian component of the study was funded by the WHO, as well as by the General Laboratory Division, National Health Foundation, Health Surveillance Secretariat, Ministry of Health, and National Research Council (CNPq), grant no 475668/03.

We are grateful to the Serology team from the National Reference Laboratory for Viral Hepatitis (NRLVH), FIOCRUZ, for processing samples and performing HCV serology; to Lucy D'Alva de Almeida and Vivian Faria (NRLVH) for HCV-RNA detection and HCV genotyping tests; and to the Harm Reduction Program team for their excellent work with this difficult-toreach and marginalized population.

\section{References}

1. United Nations. World drug report. http://www. unodc.org/unodc/en/world_drug_report.html (accessed on 17/May/2005).

2. Centers for Diseases Control and Prevention. Recommendations for prevention and control of hepatitis C virus (HCV) infection and HCV-related chronic disease. MMWR Morb Mortal Wkly Rep 1998; 47:1-39.

3. Wiessing L, Roy K, Sapinho D, Hay G, Taylor A, Goldberg D, et al. Surveillance of hepatitis C infection among injecting drug users in the European Union. In: Jager J, Limburg W, Kretzschman M, Postma M, Weissing L, editors. Hepatitis C and injecting drug use: impact, costs and policy options. Luxembourg: Office for Official Publications of the European Communities; 2004. p. 91130. (EMCDDA Monographs, 7).

4. Thorpe LE, Ouellet LJ, Hershow R, Bailey SL, Williams IT, Williamson J, et al. Risk of hepatitis C virus infection among young adult injection drug users who share injection equipment. Am J Epidemiol 2002; 155:645-53.

5. Hahn JA, Page-Shafer K, Lum PJ, Bourgois P, Stein E, Evans JL, et al. Hepatitis C virus seroconversion among young injection drug users: relationships and risks. J Infect Dis 2002; 186:1558-64.
6. Hagan H, Thiede H, Des Jarlais DC. Hepatitis C virus infection among injection drug users: survival analysis of time to seroconversion. Epidemiology 2004; 15:543-9.

7. Crofts N, Jolley D, Kaldor J, van Beek I, Wodak A. Epidemiology of hepatitis $\mathrm{C}$ virus infection among injecting drug users in Australia. J Epidemiol Community Health 1997; 51:692-7.

8. Sulkowski MS, Thomas DL. Viral hepatitis among injecting drug users. Viral Hepatitis Reviews 1998; 4: 229-44.

9. Oliveira ML, Bastos FI, Telles PR, Yoshida CF Schatzmayr HG, Paetzold U, et al. Prevalence and risk factors for $\mathrm{HBV}, \mathrm{HCV}$ and $\mathrm{HDV}$ infections among injecting drug users from Rio de Janeiro, Brazil. Braz J Med Biol Res 1999; 32:1107-14.

10. Roy E, Haley N, Leclerc P, Cedras L, Boivin JF. Drug injection among street youth: the first time. Addiction 2002; 97:1003-9.

11. Hernández-Aguado I, Ramos-Rincón JM, Avinio MJ, González-Aracil J, Pérez-Hoyos S, de la Hera MG, et al. Epidemiology and prevention of HIV disease study group: measures to reduce HIV infection have not been successful to reduce the prevalence of HCV in intravenous drug users. Eur J Epidemiol 2001; 17:539-44. 
12. Des Jarlais DC, Perlis T, Arasteh K, Torian LV, Hagan $\mathrm{H}$, Beatrice $\mathrm{S}$, et al. Reductions in hepatitis $\mathrm{C}$ virus and HIV infections among injecting drug users in New York City, 1990-2001. AIDS 2005; 19:S20-5.

13. Oliveira SAN, Hacker MA, Oliveira MLA, Yoshida CFT, Telles PR, Bastos FI. A window of opportunity: declining rates of hepatitis B virus infection among injection drug users in Rio de Janeiro, and prospects for targeted hepatitis B vaccination. Rev Panam Salud Pública 2005; 18:271-7.

14. Bastos FI, Bongertz V, Teixeira SL, Morgado MG, Hacker MA. Is human immunodeficiency virus/ acquired immunodeficiency syndrome decreasing among Brazilian injection drug users? Recent findings and how to interpret them. Mem Inst Oswaldo Cruz 2005; 100:91-6.

15. Garfein RS, Doherty MC, Monterroso ER, Thomas DL, Nelson KE, Vlahov D. Prevalence and incidence of hepatitis $\mathrm{C}$ virus infection among young adult injection drug users. J Acquir Immune Defic Syndr Hum Retrovirol 1998; 18 Suppl 1:S11-9.

16. Crofts N, Louie R, Rosenthal D, Jolley D. The first hit: circumstances surrounding initiation into injecting. Addiction 1996; 91:1187-96.

17. Roy E, Haley N, Leclerc P, Cedras L, Blais L, Boivin JF. Drug injection among street youths in Montreal: predictors of initiation. J Urban Health 2003; 80:92-105.

18. Novelli LA, Sherman SG, Havens JR, Strathdee SA, Sapun M. Circumstances surrounding the first injection experience and their association with future syringe sharing behaviors in young urban injection drug users. Drug Alcohol Depend 2005; 77:303-9.

19. Day CA, Ross J, Dietze P, Dolan K. Initiation to heroin injecting among heroin users in Sydney, Australia: cross sectional survey. Harm Reduct J $2005 ; 2: 2$.

20. Watters JK, Biernacki P. Targeted sampling-options for the study of hidden populations. Soc Probl 1989; 36:416-30.

21. de Oliveira JM, Rispeter K, Viazov S, Saback FL, Roggendorf M, Yoshida CF. Differences in HCV antibody patterns in haemodialysis patients infected with the same virus isolate. J Med Virol $2001 ; 63: 265-70$.

22. Teixeira SL, Bastos FI, Telles PR, Hacker MA, Brigido LF, Oliveira CAF, et al. HIV-1 infection among injection and ex-injection drug users from Rio de Janeiro, Brazil: prevalence, estimated incidence and genetic diversity. J Clin Virol 2004; 31:221-6.

23. Grund JP, Friedman SR, Stern LS, Jose B, Neaigus A, Curtis R, et al. Syringe-mediated drug sharing among injecting drug users: patterns, social context and implications for transmission of bloodborne pathogens. Soc Sci Med 1996; 42:691-703.

24. Galduroz JC, Noto AR, Nappo SA, Carlini EA. Trends in drug use among students in Brazil: analysis of four surveys in 1987, 1989, 1993 and 1997. Braz J Med Biol Res 2004; 37:523-31.

25. Silva OA, Yonamine M. Drug abuse among workers in Brazilian regions. Rev Saúde Pública 2004; 38:552-6.
26. Galduróz JC, Noto AR, Nappo SA, Carlini EA. Household survey on drug abuse in Brazil: study involving the 107 major cities of the country 2001. Addict Behav 2005; 30:545-56.

27. Carvalho HB, Mesquita F, Massad E, Bueno RC, Lopes GT, Ruiz MA, et al. HIV and infections of similar transmission patterns in a drug injectors community of Santos, Brazil. J. J Acquir Immune Defic Syndr Hum Retrovirol 1996; 12:84-92.

28. Barcellos NT, Fuchs SC, Fuchs FD. Prevalence of and risk factors for HIV infection in individuals testing for HIV at counseling centers in Brazil. Sex Transm Dis 2003; 30:166-73.

29. Pechansky F, Von Diemen L, Inciardi JA, Surratt H, De Boni R. Fatores de risco para transmissão do HIV em usuários de drogas de Porto Alegre, Rio Grande do Sul, Brasil. Cad Saúde Pública 2004; 20:1651-60.

30. Dunn J, Laranjeira RR. Transitions in the route of cocaine administration: characteristics, direction and associated variables. Addiction 1999; 94:81324.

31. Vidal-Trecan G, Varescon-Pousson I, Gagnière B. Injection risk behaviors at the first and at the most recent injections among drug users. Drug Alcohol Depend 2002; 66:107-9.

32. Strang J, Des Jarlais DC, Griffiths P, Gossop M. The study of transitions in the route of drug use: the route from one route to another. Br J Addict 1992; 87:473-83.

33. Mesquita F, Kral A, Reingold A, Bueno R, Trigueiros D, Araujo PJ, et al. Trends of HIV infection among injection drug users in Brazil in the 1990s: the impact of changes in patterns of drug use. J Acquir Immune Defic Syndr 2001; 28:298-302.

34. Vlahov D, Fuller CM, Ompad DC, Galea S, Des Jarlais DC. Updating the infection risk reduction hierarchy: preventing transition into injection. J Urban Health 2004; 81:14-9.

35. Powis B, Griffiths P, Gossop M, Strang J. The differences between male and female drug users: community samples of heroin and cocaine users compared. Subst Use Misuse 1996; 31:529-43.

36. Lum PJ, Sears C, Guydish J. Injection risk behavior among women syringe exchangers in San Francisco. Subst Use Misuse 2005; 40:1681-96.

37. Evans JL, Hahn JA, Page-Shafer K, Lum PJ, Stein ES, Davidson PJ, et al. Gender differences in sexual and injection risk behavior among active young injection drug users in San Francisco (the UFO Study). J Urban Health 2003; 80:137-46.

38. Miller CL, Johnston C, Spittal PM, Li K, Laliberte $\mathrm{N}$, Montaner JS, et al. Opportunities for prevention: hepatitis $\mathrm{C}$ prevalence and incidence in a cohort of young injection drug users. Hepatology 2002; 36:737-42.

39. Irwin KL, Edlin BR, Faruque S, McCoy HV, Word C, Serrano Y, et al. Crack cocaine smokers who turn to drug injection: characteristics, factors associated with injection, and implications for HIV transmission. Drug Alcohol Depend 1994; 42:8592.

40. Bravo MJ, Barrio G, de la Fuente L, Royuela L, Domingo L, Silva T. Reasons for selecting an ini- 
tial route of heroin administration and for subsequent transitions during a severe HIV epidemic. Addiction 2003; 98:749-60.

41. Neaigus A, Friedman SR, Jose B, Goldstein MF, Curtis R, Ildefonso G, et al. High-risk personal networks and syringe sharing as risk factors for HIV infection among new drug injectors. J Acquir Immune Defic Syndr Hum Retrovirol 1996; 11:499509.

42. Levine OS, Vlahov D, Koehler J, Cohn S, Spronk AM, Nelson KE. Seroepidemiology of hepatitis B virus in a population of injecting drug users. Association with drug injection patterns. Am J Epidemiol 1995; 142:331-41.

43. Stark K, Muller R, Bienzle U, Guggenmoos-Holzmann I. Frontloading: a risk factor for HIV and hepatitis $\mathrm{C}$ virus infection among injecting drug users in Berlin. AIDS 1996; 10:311-7.
44. Samuel MC, Doherty PM, Bulterys M, Jenison SA. Association between heroin use, needle sharing and tattoos received in prison with hepatitis $B$ and $C$ positivity among street-recruited injecting drug users in New Mexico, USA. Epidemiol Infect 2001; 127:475-84.

45. Stark K, Bienzle U, Vonk R, Guggenmoos-Holzmann I. History of syringe sharing in prison and risk of hepatitis $B$ virus, hepatitis $C$ virus, and human immunodeficiency virus infection among injecting drug users in Berlin. Int J Epidemiol 1997; 26:1359-66.

46. Becker Buxton M, Vlahov D, Strathdee SA, Des Jarlais DC, Morse EV, Ouellet L, et al. Association between injection practices and duration of injection among recently initiated injection drug users. Drug Alcohol Depend 2004; 75:177-83.

Submitted on 11/Oct/2005

Final version resubmitted on $01 / \mathrm{Dec} / 2005$

Approved on 16/Dec/2005 